
59 BULAN

\title{
RISK FACTORS OF STUNTING EVENTS IN TODDLERS AGED 24- 59 MONTHS
}

\section{Mufidah Binti Eka ${ }^{1}$, Ilya Krisnana ${ }^{2}$, Dominicus Husada}

1. Midwifery Study Programme, Faculty of Medicine, Universitas Airlangga, Surabaya, Indonesia

2. Maternity and Child Nursing Department, Faculty of Nursing, Universitas Airlangga, Surabaya, Indonesia

3. Pediatrics Department, Faculty of Medicine, Universitas Airlangga, Surabaya, Indonesia

Alamat korespondensi:

Jalan Kedung Asem IX/15 D Rungkut, Surabaya, Indonesia

Email : mufidah.eka123@gmail.com

\begin{abstract}
Abstrak
Latar Belakang: Stunting adalah salah satu prioritas utama di antara problem kesehatan di Indonesia. Kejadian stunting pada balita di Puskesmas Tambak Wedi Surabaya pada tahun 2015 dan 2016 sebesar $31,3 \%$ dan 33\%. Penelitian ini bertujuan menganalisis faktor risiko kejadian stunting pada balita usia 2459 bulan di wilayah kerja Puskesmas Tambak Wedi Surabaya. Metode: Penelitian analitik observasional ini dilakukan dengan pendekatan cross sectional. Sampel diambil secara proportional cluster random sampling dari populasi $220 \mathrm{ibu}$ yang berada di wilayah kerja Puskesmas Tambak Wedi Surabaya. Variabel independen pada ibu meliputi tinggi badan, riwayat lingkar lengan atas, riwayat frekuensi kunjungan ANC, dan riwayat peningkatan berat badan saat hamil, serta pada balita meliputi panjang badan lahir dan berat badan lahir. Variabel dependen adalah kejadian stunting. Analisis statistik menggunakan uji chi-square dan regresi logistik berganda. Hasil: Sampel penelitian berjumlah 110 pasang ibu dan balita. Hasil bivariat menunjukkan ada hubungan antara tinggi badan ibu $(\mathrm{p}=0,025, \mathrm{RR}=0,406)$, frekuensi kunjungan ANC $(p=0,017, R R=0,382)$, peningkatan berat badan ibu saat hamil $(p=0,017, R R=0,328)$, panjang badan lahir bayi $(\mathrm{p}=<0,001, \mathrm{RR}=0,256)$, dan berat badan lahir bayi $(\mathrm{p}=<0,001, \mathrm{RR}=0,208)$ dengan kejadian stunting. Hasil multivariat menunjukkan tinggi badan ibu dan kunjungan ANC merupakan faktor risiko yang bermakna. Kesimpulan: Tinggi badan ibu dan frekuensi kunjungan ANC merupakan faktor risiko kejadian stunting balita usia 24-59 bulan di wilayah kerja Puskesmas Tambak Wedi Surabaya.
\end{abstract}

Kata kunci : stunting, faktor risiko balita

Abstract

Background: Stunting is one priority problem in Indonesia. The incidence of stunting in toddlers at the Tambak Wedi Public Health Center Surabaya in 2015 and 2016 were 31.3\% and 33\%, respectively. This study aims to analyze the risk factors for stunting in toddlers aged 24-59 months in Tambak Wedi Health Center Surabaya. Method: This observational analytic research used cross sectional approach. The population in this study was 220 and the sample size was 110 mothers and toddlers. Samples were selected by proportional cluster random sampling from the population of 220 pairs mothers and toddlers. Independent variables of the mothers include height, upper arm circumference, frequency of ANC visits, weight gain during pregnancy, meanwhile of the toddlers included birth length and birth weight. The dependent variable was stunting. Statistical analysis used chi-square and multiple logistic regression tests. Results: There were 100 pairs of mother and toddlers in the study. Bivariate analysis showed a significant relationship between maternal height ( $p=0.025, R R=0.406)$, frequency of ANC visits $(p=0.017, R R=$ $0.382)$, increase in maternal weight during pregnancy $(p=0.017, R R=0.328)$, the baby's birth length ( $p$ 
$=<0.001, R R=0.256)$, and the baby's birth weight $(p=<0.001, R R=0.208)$ with stunting. Multivariate analysis showed maternal height and ANC visit as the significant risk factors of stunting. Conclusion: Maternal height and the frequency of ANC visits were the risk factors for stunting among toddlers aged 2459 months in Tambak Wedi Public Health Center in Surabaya.

Keywords: stunting, toddlers risk factors

\section{PENDAHULUAN}

Stunting merupakan masalah pertumbuhan balita yang masih memiliki angka tertinggi di Asia (Kemenkes RI, 2016). Masalah gizi kurang memiliki kaitan dengan kejadian stunting yang merupakan masalah signifikan yang menetap (Govindaraj, et.al., 2015). Menurut penelitian sebelumnya kejadian stunting di Puskesmas Tambak Wedi Kota Surabaya tahun 2015 terdapat 335 balita stunting dari 1067 balita atau sebesar 31,3\%, dan tahun 2016 prevalensi balita stunting meningkat menjadi 33\% (Losong, 2017). Stunting dapat menyebabkan anak menjadi mudah sakit, dapat mengakibatkan kerugian ekonomi baik pada keluarga maupun negara, bentuk postur tubuh tidak dapat maksimal saat dewasa, fungsi tubuh menjadi tidak seimbang, serta dampak buruk yang sangat dikhawatirkan ialah kemampuan kognitif pada anak menjadi berkurang. Oleh karena itu, stunting merupakan masalah urgensi bagi pemerintah kesehatan (Kemenkes RI, 2017).

Asupan nutrisi yang kurang dapat terjadi karena makanan yang dikonsumsi tidak sesuai dengan kebutuhan pertumbuhan badan dan kebutuhan gizi dari segi kuantitatif maupun kualitatif(Irianton A, 2015). Selain itu tinggi badan ibu dikatakan menjadi faktor mendasar karena faktor genetik tinggi badan dapat diwariskan melalui ibu. Ibu dengan tinggi badan pendek dapat mempengaruhi tinggi badan anak kelak (Thomas, 2010). Riwayat LILA merupakan faktor mendasar karena ibu dengan LILA $<23,5 \mathrm{~cm}$ dapat diartikan bahwa asupan yang dikonsumsi sebelum hamil kurang dan jika tidak dilakukan pemenuhan gizi secepatnya maka dapat menyebabkan masalah gizi pada anak yang dilahirkan. Oleh karena itu status gizi ibu sebelum hamil harus tercukupi sehingga dapat menstransfer nutrisi dari ibu ke janin. Pengukuran panjang LILA dilakukan saat awal pemeriksaan kehamilan. Pada pelaksanaan Antenatal Care (ANC) akan dilakukan observasi secara kontinu dan secara reguler. Perkembangan janin akan dipantau dan apabila terjadi perubahan pada perkembangan janin maka akan diinformasikan kepada ibu. Ibu yang memiliki kesadaran akan pentingnya melakukan pemeriksaan kehamilan dapat menurunkan risiko terjadinya hal yang tidak diinginkan pada janin (Purwaningsih \& Fatmawati, 2010). Serta riwayat panjang dan berat badan lahir bayi yang rendah 
merupakan faktor masalah gizi pada anak. Asupan gizi ibu yang kurang saat hamil dapat mempengaruhi ukuran panjang badan lahir dan berat badan lahir bayi yang rendah (Sari, 2018). Sehingga hal tersebut mempengaruhi terjadinya stunting.

\section{METODE}

Jenis penelitian ini menggunakan Analitik Observasional dengan desain penelitian Cross Sectional. Populasi dalam penelitian ini yaitu balita yang memiliki ibu sesuai dengan kriteria inklusi dan eksklusi yang datang ke posyandu di wilayah kerja Puskesmas Tambak Wedi Surabaya, sejumlah 220 ibu dan balita. Teknik sampel menggunakan Proporsional Cluster Random Sampling. Besar sampel pada penelitian ini menggunakan program komputerisasi WHO sample size dengan memasukkan nilai $\alpha 5 \%, 1-\beta$, P1 sebesar 0.33, dan P2 sebesar 0,67 berdasarkan pada penelitian yang dilakukan sebelumnya pada tahun 2017, dan didapatkan hasil besar sampel minimal yaitu 100 sampel. Pada pelaksanaan penelitian, didapatkan 110 responden.

Kriteria inklusi maupun eksklusi dibagi menjadi 2, yaitu pada ibu dan balita. Kriteria inklusi pada ibu antara lain ibu yang memiliki balita usia 24-59 bulan, memiliki buku KIA lengkap, dan bersedia menjadi responden dengan menandatangani lembar informed consent. Sedangkan kriteria inklusi pada balita antara lain balita usia 24-59 bulan, sehat dan dapat dilakukan pengukuran status gizi dengan indeks TB/U. Kriteria eksklusi pada ibu yaitu ibu yang memiliki gangguan mental, dan kriteria eksklusi pada balita yaitu balita dengan penyakit kronik (kelainan jantung, kelainan genetik tertentu, dll). Variabel bebas pada penelitian ini meliputi tinggi badan ibu, LILA ibu saat hamil, frekuensi kunjungan ANC, peningkatan berat badan saat hamil, panjang badan lahir bayi, dan berat badan lahir bayi. Variabel terikat yaitu kejadian stunting.

Pengumpulan data dilakukan pada bulan Maret - Mei 2020. Sebelum dilakukan pengambilan data pada responden, peneliti terlebih dahulu menjelaskan maksud dan tujuan penelitian serta meminta kesediaan menjadi responden pada lembar Informed Consent. Pengolahan data dilakukan dengan editing, coding, data entry, cleaning, dan analisis data. Kemudian data diolah dengan analisis bivariat menggunakan uji statistik Chi-Square dan analisis multivariat menggunakan uji regresi logistik berganda dengan bantuan program komputer SPSS. 


\section{HASIL DAN PEMBAHASAN}

\section{Tinggi Badan Ibu Saat Hamil}

Tinggi badan ibu dibagi dalam dua kategori yaitu tinggi dan pendek. Dari 23 balita stunting, 10 balita dengan ibu kategori tinggi serta 13 balita dengan ibu kategori pendek. Selengkapnya dapat dilihat pada tabel berikut.

Tabel 2 Tinggi Badan Ibu Saat Hamil dengan Kejadian Stunting di Wilayah Kerja Puskesmas Tambak Wedi Surabaya.

\begin{tabular}{|c|c|c|c|c|c|c|c|c|}
\hline \multirow[t]{3}{*}{ Tinggi Badan Ibu Saat Hamil } & \multicolumn{4}{|c|}{ Kejadian Stunting } & \multirow{2}{*}{\multicolumn{2}{|c|}{ Total }} & \multirow{3}{*}{ P value } & \multirow{3}{*}{$\mathbf{R R}$} \\
\hline & \multicolumn{2}{|c|}{ Stunting } & \multicolumn{2}{|c|}{$\begin{array}{c}\text { Tidak } \\
\text { Stunting }\end{array}$} & & & & \\
\hline & $\mathbf{n}$ & $\%$ & $\mathbf{n}$ & $\%$ & $\mathbf{n}$ & $\%$ & & \\
\hline Tinggi & 10 & 13,9 & 62 & 86,1 & 72 & 65,5 & \multirow{3}{*}{0,025} & \multirow{3}{*}{0,406} \\
\hline Pendek & 13 & 34,2 & 25 & 65,8 & 38 & 54,5 & & \\
\hline Total & 23 & 20,9 & 87 & 79,1 & 110 & 100 & & \\
\hline
\end{tabular}

Tabel 2 hasil uji Chi-Square didapatkan nilai $\mathrm{p}$ value $=0,025$ yang dapat disimpulkan bahwa ada hubungan tinggi badan ibu saat hamil dengan kejadian stunting. Serta didapatkan nilai Relative Risk sebesar 0,406 sehingga dapat dianggap RR tidak bermakna.

\section{Lingkar Lengan Atas (LILA) Ibu Saat Hamil}

Penilaian gizi berdasarkan panjang LILA dibagi dalam dua kategori yaitu gizi baik dan gizi kurang. Dari 23 balita stunting, 19 balita dengan ibu kategori gizi baik serta 4 balita dengan ibu kategori gizi kurang. Selengkapnya dapat dilihat pada tabel berikut.

Tabel 3 LILA Ibu Saat Hamil dengan Kejadian Stunting di Wilayah Kerja Puskesmas Tambak Wedi Surabaya

\begin{tabular}{|c|c|c|c|c|c|c|c|}
\hline \multirow[t]{3}{*}{ LILA Ibu Saat Hamil } & \multicolumn{4}{|c|}{ Kejadian Stunting } & & & \multirow{3}{*}{ P value } \\
\hline & \multicolumn{2}{|c|}{ Stunting } & \multicolumn{2}{|c|}{ Tidak Stunting } & \multicolumn{2}{|c|}{ Total } & \\
\hline & $\mathbf{n}$ & $\%$ & n & $\%$ & $\mathbf{n}$ & $\%$ & \\
\hline Gizi Baik & 19 & 21,8 & 68 & 78,2 & 87 & 79,1 & \\
\hline Gizi Kurang & 4 & 17,4 & 19 & 82,6 & 23 & 20,9 & 0,778 \\
\hline Total & 23 & 20,9 & 87 & 79,1 & 110 & 100 & \\
\hline
\end{tabular}

Tabel 3 hasil uji Fisher's Exact didapatkan nilai p value=0,778 yang dapat disimpulkan bahwa tidak ada hubungan LILA ibu saat hamil dengan kejadian stunting.

\section{Frekuensi Kunjungan ANC}

Frekuensi kunjungan ANC dibagi dalam dua kategori yaitu sesuai anjuran dan tidak sesuai anjuran. Dari 23 balita stunting, 13 balita dengan ibu kategori sesuai 
anjuran serta 10 balita dengan ibu kategori tidak sesuai anjuran. Selengkapnya dapat dilihat pada tabel berikut.

Tabel 4 Frekuensi Kunjungan ANC dengan Kejadian Stunting di Wilayah Kerja Puskesmas Tambak Wedi Surabaya

\begin{tabular}{|c|c|c|c|c|c|c|c|c|}
\hline \multirow[t]{3}{*}{ Frekuensi Kunjungan ANC } & \multicolumn{4}{|c|}{ Kejadian Stunting } & \multirow{2}{*}{\multicolumn{2}{|c|}{ Total }} & \multirow{3}{*}{ P value } & \multirow{3}{*}{$\mathbf{R R}$} \\
\hline & \multicolumn{2}{|c|}{ Stunting } & \multicolumn{2}{|c|}{$\begin{array}{c}\text { Tidak } \\
\text { Stunting }\end{array}$} & & & & \\
\hline & $\mathbf{n}$ & $\%$ & $\mathbf{n}$ & $\%$ & $\mathbf{n}$ & $\%$ & & \\
\hline Sesuai Anjuran & 13 & 15,3 & 72 & 84,7 & 85 & 72,3 & \multirow{3}{*}{0,017} & \multirow{3}{*}{0,382} \\
\hline Tidak Sesuai Anjuran & 10 & 40,0 & 15 & 60,0 & 25 & 22,7 & & \\
\hline Total & 23 & 20,9 & 87 & 79,1 & 110 & 100 & & \\
\hline
\end{tabular}

Tabel 4 hasil uji Chi-Square didapatkan nilai $\mathrm{p}$ value $=0,017$ yang dapat disimpulkan bahwa ada hubungan frekuensi kunjungan ANC dengan kejadian stunting. Serta didapatkan nilai Relative Risk sebesar 0,382 sehingga dapat dianggap RR tidak bermakna.

\section{Peningkatan Berat Badan Ibu Saat Hamil}

Peningkatan berat badan ibu saat hamil dibagi dalam dua kategori yaitu sesuai anjuran dan tidak sesuai anjuran. Dari 23 balita stunting, 4 balita dengan ibu kategori sesuai anjuran serta 19 balita dengan ibu kategori tidak sesuai anjuran. Selengkapnya dapat dilihat pada tabel berikut.

Tabel 5 Peningkatan Berat Badan Ibu Saat Hamil dengan Kejadian Stunting di Wilayah Kerja Puskesmas Tambak Wedi Surabaya

\begin{tabular}{|c|c|c|c|c|c|c|c|c|}
\hline \multirow{3}{*}{$\begin{array}{c}\text { Peningkatan BB Ibu Saat } \\
\text { Hamil }\end{array}$} & \multicolumn{4}{|c|}{ Kejadian Stunting } & \multirow{2}{*}{\multicolumn{2}{|c|}{ Total }} & \multirow{3}{*}{ Pvalue } & \multirow{3}{*}{$\mathbf{R R}$} \\
\hline & \multicolumn{2}{|c|}{ Stunting } & \multicolumn{2}{|c|}{$\begin{array}{c}\text { Tidak } \\
\text { Stunting } \\
\end{array}$} & & & & \\
\hline & $\mathbf{n}$ & $\%$ & $\mathbf{n}$ & $\%$ & $\mathbf{n}$ & $\%$ & & \\
\hline Sesuai Anjuran & 4 & 9,3 & 39 & 90,7 & 43 & 39,1 & & \\
\hline Tidak Sesuai Anjuran & 19 & 28,4 & 48 & 71,6 & 67 & 60,9 & & \\
\hline Total & 23 & 20,9 & 87 & 79,1 & 110 & 100 & 0,017 & 0,328 \\
\hline
\end{tabular}

Tabel 5 hasil uji Fisher's Exact didapatkan nilai p value=0,017 yang dapat disimpulkan bahwa ada hubungan peningkatan berat badan ibu saat hamil dengan kejadian stunting. Serta didapatkan nilai Relative Risk sebesar 0,328 sehingga dapat dianggap RR tidak bermakna.

\section{Panjang Badan Lahir Bayi}

Panjang badan lahir bayi dibagi dalam dua kategori yaitu normal dan Panjang Badan Lahir Rendah (PBLR). Dari 23 balita stunting, 11 balita dengan riwayat panjang 
badan lahir normal serta 12 balita dengan riwayat PBLR. Selengkapnya dapat dilihat pada tabel berikut.

Tabel 6 Panjang Badan Lahir Bayi dengan Kejadian Stunting di Wilayah Kerja Puskesmas Tambak Wedi Surabaya

\begin{tabular}{|c|c|c|c|c|c|c|c|c|}
\hline \multirow[t]{3}{*}{ Panjang Badan Lahir Bayi } & \multicolumn{4}{|c|}{ Kejadian Stunting } & & & \multirow{3}{*}{ P value } & \multirow{3}{*}{$\mathbf{R R}$} \\
\hline & \multicolumn{2}{|c|}{ Stunting } & \multicolumn{2}{|c|}{$\begin{array}{c}\text { Tidak } \\
\text { Stunting }\end{array}$} & \multicolumn{2}{|c|}{ Total } & & \\
\hline & $\mathbf{n}$ & $\%$ & $\mathbf{n}$ & $\%$ & $\mathbf{n}$ & $\%$ & & \\
\hline Normal & 11 & 12,8 & 75 & 87,2 & 86 & 78,2 & & \\
\hline PBLR & 12 & 50,0 & 12 & 50,0 & 24 & 21,8 & $<0,001$ & 0,256 \\
\hline Total & 23 & 20,9 & 87 & 79,1 & 110 & 100 & & \\
\hline
\end{tabular}

Tabel 6 hasil uji Chi-Square didapatkan nilai p value $=<0,001$ yang dapat disimpulkan bahwa ada hubungan panjang badan lahir bayi dengan kejadian stunting. Serta didapatkan nilai Relative Risk sebesar 0,256 sehingga dapat dianggap RR tidak bermakna.

\section{Berat Badan Lahir Bayi}

Berat badan lahir bayi dibagi dalam dua kategori yaitu normal dan Berat Badan Lahir Rendah (BBLR). Dari 23 balita stunting, 15 balita dengan riwayat berat badan lahir normal serta 8 balita dengan riwayat BBLR. Selengkapnya dapat dilihat pada tabel berikut.

Tabel 7 Berat Badan Lahir Bayi dengan Kejadian Stunting di Wilayah Kerja Puskesmas Tambak Wedi Surabaya

\begin{tabular}{|c|c|c|c|c|c|c|c|c|}
\hline \multirow[t]{3}{*}{ Berat Badan Lahir Bayi } & \multicolumn{4}{|c|}{ Kejadian Stunting } & \multirow{2}{*}{\multicolumn{2}{|c|}{ Total }} & \multirow{3}{*}{ P value } & \multirow{3}{*}{ OR } \\
\hline & \multicolumn{2}{|c|}{ Stunting } & \multicolumn{2}{|c|}{$\begin{array}{c}\text { Tidak } \\
\text { Stunting } \\
\end{array}$} & & & & \\
\hline & $\mathbf{n}$ & $\%$ & $\mathbf{n}$ & $\%$ & $\mathbf{n}$ & $\%$ & & \\
\hline Normal & 15 & 15,2 & 84 & 84,8 & 99 & 90,0 & & \\
\hline BBLR & 8 & 72,7 & 3 & 27,3 & 11 & 10,0 & $<0,001$ & 0,208 \\
\hline Total & 23 & 20,9 & 87 & 79,1 & 110 & 100 & & \\
\hline
\end{tabular}

Tabel 7 hasil uji Fisher's Exact didapatkan nilai p value $=<0,001$ yang dapat disimpulkan bahwa ada hubungan berat badan lahir bayi dengan kejadian stunting. Serta didapatkan nilai Relative Risk sebesar 0,208 sehingga dapat dianggap RR tidak bermakna.

\section{Analisis Multivariat}

Hasil analisis bivariat diperoleh variabel yang ada hubungan signifikan dengan kejadian stunting yaitu tinggi badan ibu, peningkatan berat badan ibu saat hamil, panjang badan lahir bayi, dan berat badan lahir bayi. Selanjutnya dilakukan analisis regresi logistik berganda pada tabel 8 . 
Tabel 8 Hasil Analisis Multivariat dengan Uji Regresi Logistik Berganda

\begin{tabular}{lccccc}
\hline \multicolumn{1}{c}{ Variabel } & B & P value & Exp (B) & \multicolumn{2}{c}{ 95\% C.I for Exp(B) } \\
\hline Tinggi Badan Ibu Saat Hamil & $-1,339$ & 0,023 & 0,262 & 0,083 & 0,828 \\
\hline Frekuensi Kunjungan ANC & $-1,640$ & 0,010 & 0,194 & 0,056 & 0,670 \\
\hline Peningkatan BB Ibu Saat Hamil & $-0,916$ & 0,179 & 0,400 & 0,105 & 1,524 \\
\hline Panjang Badan Lahir Bayi & $-1,072$ & 0,122 & 0,342 & 0,088 & 1,331 \\
\hline Berat Badan Lahir Bayi & $-1,675$ & 0,076 & 0,187 & 0,029 & 1,193 \\
\hline
\end{tabular}

Tabel 8 menunjukkan bahwa faktor risiko yang menjadi faktor dominan pada kejadian stunting pada balita usia 24-59 bulan di wilayah kerja Puskesmas Tambak Wedi adalah tinggi badan ibu saat hamil dan frekuensi kunjungan ANC. Ibu yang memiliki tinggi badan pendek dapat meningkatkan kejadian stunting 0,262 lebih besar dibandingkan ibu yang memiliki tinggi badan normal, serta riwayat frekuensi ANC yang tidak sesuai anjuran berpeluang 0,194 kali memiliki balita stunting.

Hasil penelitian ini menunjukkan bahwa variabel tinggi badan ibu saat hamil, frekuensi kunjungan ANC, peningkatan berat badan ibu saat hamil, panjang badan lahir bayi, dan berat badan lahir bayi memiliki hubungan dengan kejadian stunting pada balita usia 24-59 bulan di wilayah kerja Puskesmas Tambak Wedi Surabaya. Serta hasil pada analisis multivariat menunjukkan bahwa variabel tinggi badan ibu saat hamil dan frekuensi kunjungan ANC merupakan faktor risiko dominan pada penelitian ini. Pada hasil uji Fisher's Exact untuk variabel LILA ibu saat hamil didapatkan nilai $\mathrm{p}$ value $=0,778$ dan dapat disimpulkan bahwa tidak ada hubungan antara LILA ibu dengan kejadian stunting pada balita usia 24-59 bulan di wilayah kerja Puskesmas Tambak Wedi Surabaya.

Penelitian ini sejalan dengan penelitian Nadia (2018) yang dilakukan di wilayah Puskesmas Wonosari II menunjukkan bahwa terdapat hubungan antara tinggi badan ibu dengan kejadian stunting. Serta hasil uji multivariat menunjukkan bahwa variabel tinggi badan ibu merupakan variabel dominan yang berpengaruh terhadap kejadian stunting. Faktor genetik merupakan salah satu faktor yang dapat mempengaruhi keadaan seseorang dan dapat diturunkan salah satunya yaitu tinggi badan. Tinggi badan ibu yang pendek memiliki peranan yang penting pada kejadian stunting (Rachmi et al., 2016).

Ibu hamil dengan masalah gizi kurang (KEK) jika LILA lebih kecil dari 23,5 $\mathrm{cm}$. Penentuan status gizi pada ibu hamil adalah normal jika LILA $\geq 23,5 \mathrm{~cm}$ dan KEK 
jika LILA <23,5 cm (Kemenkes RI, 2015). Pada variabel LILA ibu saat hamil, penelitian ini sejalan dengan penelitian di Yogyakarta oleh Kristiana dkk. (2016) bahwa riwayat KEK saat hamil dengan kejadian stunting pada balita. Hasil serupa juga sejalan dengan Astuti (2016) di desa Hargorejo Kulonprogo Yogyakarta. Penelitian ini berbeda dengan hasil penelitian yang dilakukan oleh Sukmawati pada tahun 2018. Penelitian tersebut mengatakan bahwa terdapat hubungan antara riwayat KEK saat hamil dengan kejadian stunting. Tidak terdapat hubungan pada penelitian ini karena adanya kesadaran ibu hamil untuk memeriksakan kehamilan secara rutin sudah tinggi, yaitu sebesar 77,3\%. Dengan demikian ibu hamil dengan LILA kurang dari 23,5 cm dapat dilakukan intervensi sedini mungkin oleh tenaga kesehatan.

Variabel frekuensi kunjungan ANC pada penelitian ini sejalan dengan penelitian Sholikin (2015), bahwa ibu dengan kunjungan dan kualitas ANC yang kurang memiliki risiko melahirkan bayi dengan berat lahir rendah (BBLR). BBLR merupakan salah satu faktor risiko yang berperan dengan kejadian stunting. Saat kunjungan ANC ibu hamil akan mendapatkan pemeriksaan kehamilan secara menyeluruh, mendapat konseling pendidikan kesehatan, serta mendapat suplemen asam folat dan zat besi. Sehingga hal ini diharapkan dapat mencegah terjadinya anemia pada ibu hamil, mencegah lahirnya bayi prematur dan bayi kecil, serta bayi mendapatkan kecukupan nutrisi sejak dalam kandungan. Dengan demikian dapat mengurangi angka kejadian stunting pada balita (Masta, 2020).

Pertambahan berat badan ibu saat hamil pada penelitian ini sejalan dengan penelitian Erowati (2019), yang menyatakan bahwa ibu dengan peningkatan berat badan yang kurang selama kehamilan memiliki risiko 2,15 kali dengan kejadian stunting dibandingkan dengan ibu yang status gizi normal sejak awal kehamilan. Hasil penelitian lain menyatakan bahwa ibu dengan penambahan berat badan yang tidak sesuai anjuran memiliki risiko 4,747 kali terjadinya stunting pada anak (Apriningtyas, 2018). Pertambahan berat badan ibu sehama hamil berkisar antara 10-12 kg. Pertambahan berat badan saat trimester I yaitu sebesar 1,1 kg, trimester II sebesar 2,2 $\mathrm{kg}$, dan trimester III sebesar 5,0 kg. Selain itu terjadinya perubahan mekanisme pengaturan dan fungsi organ tubuh, yaitu peningkatan aktivitas fisiologis, metabolik, dan anatomis (Hardinsyah \& Supariasa, 2017). Defisiensi zat gizi yang paling berat dan meluas pada balita ialah kekurangan zat gizi akibat kekurangan konsumsi 
makanan dan hambatan mengabsorbsi zat gizi. Kekurangan zat gizi disebabkan karena makanan yang tidak sesuai dengan kebutuhan pertumbuhan badan atau adanya ketidakseimbangan antara konsumsi zat gizi dan kebutuhan gizi dari segi kuantitatif maupun kualitatif (Irianton A, 2015). Sehingga dapat berisiko melahirkan bayi dengan BBLR (Neneng, 2019). Bayi dengan BBLR dapat berisiko 2,9 kali mengalami stunting (Amini, 2017).

Penelitian ini menunjukkan bahwa terdapat hubungan panjang badan lahir bayi dengan stunting. Penelitian ini sejalan dengan penelitian yang dilakukan oleh Damayanti, Muniroh, \& Farapti (2016) bahwa balita dengan riwayat Panjang Badan Lahir Rendah (PBLR) memiliki risiko kejadian stunting. Balita dengan riwayat PBLR berisiko stunting 2,90 kali lebih besar dibandingkan dengan balita dengan riwayat panjang badan lahir normal. Hasil tersebut juga serupa dengan penelitian yang dilakukan di Kota Kendari tahun 2016 bahwa panjang badan lahir merupakan faktor risiko kejadian stunting (Swathma, Lestari, \& Teguh, 2016). Ibu yang memiliki anak dengan PBLR, saat kehamilan ibu kurang memperhatikan asupan zat gizi. Ibu kurang mengkonsumsi makanan yang seimbang. Asupan zat gizi pada masa kehamilan sangatlah penting karena sangat dibutuhkan untuk perkembangan dan pertumbuhan janin. Jika asupan zat gizi tidak optimal maka pertumbuhan janin tidak optimal maka dapat mengakibatkan bayi yang lahir dengan PBLR (Suharmianti \& Agus, 2018).

Variabel berat badan lahir bayi pada penelitian ini sejalan dengan penelitian yang dilakukan di wilayah kerja Puskesmas Sungai Karias Provinsi Kalimantan Selatan, bahwa berat badan lahir merupakan faktor risiko yang paling dominan terhadap kejadian stunting (Rahayu dkk., 2015). Berat Badan Lahir Rendah (BBLR) berpeluang 3,63 kali memiliki risiko kejadian stunting pada balita (Wiwien dkk., 2016). Periode kehamilan hingga usia dua tahun pertama merupakan periode kritis pada anak. Gangguan pertumbuhan yang terjadi pada periode ini sulit diperbaiki dan sulit mencapai tumbuh kembang yang optimal (Rosmalina dkk., 2018). Oleh karena itu diharapkan bayi dengan berat badan lahir rendah dimaksimalkan pemberian gizi yang dapat memicu pertumbuhan pada periode ini. BBLR tidak akan mempengaruhi pertumbuhan apabila anak mendapatkan asupan yang cukup serta kondisi lingkungan yang mendukung pada perkembangan dan pertumbuhan anak (Aridiyah, Rohmawati, \& Ririanty, 2015). 


\section{KESIMPULAN DAN SARAN}

Berdasarkan penelitian yang dilakukan pada ibu dan balita usia 24-59 bulan di wilayah kerja Puskesmas Tambak Wedi Surabaya dihasilkan bahwa faktor risiko yang memiliki hubungan dengan kejadian stunting pada ibu yaitu mengenai tinggi badan, frekuensi kunjungan ANC, peningkatan berat badan ibu saat hamil. Serta faktor risiko kejadian stunting pada balita yaitu mengenai panjang badan lahir, dan berat badan lahir. Faktor risiko dominan pada penelitian ini ialah tinggi badan ibu dan frekuensi kunjungan ANC. Diharapkan pemerintah memiliki program dorongan pentingnya melakukan pemeriksaan kehamilan sesuai ajuran serta evaluasi dan perbaikan kualitas ANC di setiap pelayanan kesehatan.

\section{DAFTAR PUSTAKA}

Amini, A. (2017). Hubungan Kunjungan Antenatal Care (ANC) Dengan Kejadian Stunting Pada Balita Usia 12-59 Bulan di Kabupaten Lombok Utara Provinsi NTB Tahun 2016. Tesis. Universitas 'Aisyiyah Yogyakarta.

Apriningtyas, V. N. (2018). Faktor Prenatal yang Berhubungan Dengan Kejadian Stunting (Studi di Desa Dukuhmaja Kecamatan Songgom Kabupaten Brebes). The Indonesian Journal of Public Health, 14(2).

Aridiyah, F. O., Rohmawati, N., \& Ririanty, M. (2015). Faktor-faktor yang Dapat Mempengaruhi Kejadian stunting pada Anak Balita di Wilayah Pedesaan dan Perkotaan. E-Journal Pustaka Kesehatan, 3(1), pp. 163-70.

Astuti, D. K. (2016). Hubungan Karakteristik Ibu Dan Pola Asuh Gizi Dengan Kejadian Balita Stunted di Desa Hargorejo Kulonprogo DIY. Skripsi. Universitas Muhammadiyah Surakarta.

Damayanti, R. A., Muniroh, L., \& Farapti. (2016). Perbedaan Tingkat Kecukupan Zat Gizi dan Riwayat Pemberian ASI Eksklusif Pada Balita Stunting dan Non Stunting. Media Gizi Indonesia, 2(1), pp. 61-69.

Erowati, D. (2019). Kenaikan Berat Badan Selama Kehamilan Sebagai Faktor Resiko Kejadian Stunting Pada Anak Usia 12-24 Bulan. INA-Rxiv. Diperoleh dari: https://osf.io/preprints/inarxiv/t4b26/.

Govindaraj, R. et al. (2015). Health Care in Sri Lanka: What Can the Private Health Sector Offer? South-East Asia. Available at: https//openknowledge.worldbank.org/bitstream/handle/10986/20018/899540W P0Box380th0Care0in0Sri0Lanka.pdf.

Hardinsyah, \& Supariasa, I. D. M. (2017). Ilmu Gizi Teori dan Aplikasi. Jakarta: EGC. Irianton, A. (2015). Gizi Ibu Dan Anak. PT. Leutika Nouvalitera.

Kementerian Kesehatan Republik Indonesia. (2012) Survei Kesehatan Dasar Indonesia. Jakarta: Kementerian Kesehatan Republik Indonesia.

Kementerian Kesehatan Republik Indonesia. (2013). Permenkes Nomor 75 Tahun 2013 tentang Angka Kecukupan Gizi yang Dianjurkan Bagi Bangsa Indonesia. 
Kementerian Kesehatan Republik Indonesia, 1(1), 69-73. https://doi.org/10.11113/jt.v56.60K.

Kementerian Kesehatan Republik Indonesia. (2014) Pedoman Pelaksanaan Stimulasi, Deteksi Dini, dan Intervensi Dini Tumbuh Kembang di Tingkat pelayanan Kesehatan Dasar. Jakarta: Kementerian Kesehatan Republik Indonesia.

Kementerian Kesehatan Republik Indonesia. (2015). Status Gizi Pengaruhi Kualitas Bangsa. Jakarta: Kementerian Kesehatan Republik Indonesia.

Kementerian Kesehatan Republik Indonesia. (2016) Buku Saku Pemantauan Gizi dan Indikator Kinerja Gizi Tahun 2015. Jakarta: Badan Penelitian dan Pengembangan Kesehatan Kementerian Kesehatan.

Kementerian Kesehatan Republik Indonesia. (2017). Situasi Balita. Jakarta: Pusat Data Dan Informasi Kementerian Kesehatan Republik Indonesia.

Kristiana, T. W., Hamam, H., Detty, \& Siti, N. (2016). Riwayat KEK dan Anemia Pada Ibu Hamil Tidak Berhubungan Dengan Kejadian Stunting Pada Anak Usia 6-23 Bulan Di Kecamatan Sedayu, Bantul, Yogyakarta. Jurnal Gizi dan Dietetik Indonesia, 4(1), pp. 29-40. doi: 10.21927/ijnd.2016.4(1).29-40.

Losong, A. (2017). Perbedaan Kadar Hemoglobin, Asupan Zat Besi, dan Zink pada Balita Stunting dan non Stunting. Jurnal Amerta Nutr, 1(2), p. 121.

Masta, H., Khristina, D. U., Nur, F. A. (2020). Kunjungan Antenatal Care Berhubungan Dengan Kejadian Stunting. Jurnal Kesehatan Samodra Ilmu, 11(1). Diakses dari: https://stikes-yogyakarta.e-journal.id/JKSI/article/view/13.

Nadia, N. L., Heni, P. W., \& Margono. (2018). Faktor-Faktor Yang Berhubungan Dengan Kejadian Stunting Pada Balita Usia 25-59 Bulan Di Posyandu Wilayah Puskesmas Wonosari II Tahun 2017. Skripsi. Poltekkes Kemenkes Yogyakarta.

Neneng, S. L. (2019). Hubungan Kenaikan Berat Badan Ibu Selama Hamil Terhadap Berat Badan Bayi Saat Lahir Di BPS Wirahayu Panjang Bandar Lampung. Jurnal Ilmu Kedokteran dan Kesehatan, 6(4). doi: https://doi.org/10.33024/jikk.v6i4.2266. ISSN: 2355-7583.

Purwaningsih, W., Fatmawati, S. (2010). Asuhan Keperawatan Maternitas. Yogyakarta: Nuha Medika.

Rachmi, C. N., Agho, K. E., Li, M., \& Baur, L. A. (2016). Stunting, underweight and overweight in children aged 2.0-4.9 years in Indonesia: Prevalence trends and $\begin{array}{lllll}\text { associated risk factors. } & \text { PLOS }\end{array}$ https://doi.org/10.1371/journal.pone.0154756.

Rahayu, A., Yulidasari, F., Putri, A. O., Rahman, F. (2015). Riwayat Berat Badan Lahir Dengan Kejadian Stunting Pada Anak Usia Bawah Dua Tahun. Jurnal Kesehatan Masyarakat Nasional, 10(2), pp. 67-73.

Riset Kesehatan Dasar. (2013) Badan Penelitian dan Pengembangan Kesehatan Kementerian RI tahun 2013. Available at: dari http://www.depkes.go.id/resources/download/general/Hasil\%20Riskesdas\%20 2013.pdf. (Accessed: 19 Oktober 2014).

Rosmalina, Y., Luciasari, E., Aditianti, Ernawati, F. (2018). Upaya Pencegahan Dan Penanggulangan Batita Stunting: Systematic Review. Jurnal Gizi Indonesia, 41(1), pp. 1-14.

Sari, P., Agustin, D. S. (2018). Determinan Sosial Terhadap Kejadian Stunting Pada Anak Usia di Bawah Lima Tahun. Jurnal Kebidanan, 7(2), pp. 95-102. Diperoleh dari: http://jurnal.unimus.ac.id/index.php/jur_bid/. doi : 10.26714/jk.7.2.2018.95-102. 
Sholikin, R. A. (2015). Hubungan Antenatal Care (ANC) dengan Kejadian Bayi Berat Lahir Rendah di Kabupaten Purbalingga. Tesis. Universitas Gadjah Mada.

Suharmianti, M., Agus, H. (2018). Faktor-Faktor Yang Berhubungan Dengan Status Stunting Anak Usia 24-59 Bulan Di Wilayah Kerja Upk Puskesmas Siantan Hulu. Pontianak Nutrition Journal (PNJ), 1(1).

Swathma, D., Lestari, H., \& Teguh, A. R. (2016). Analisis Faktor Risiko BBLR, Panjang Badan Saat Lahir Dan Riwayat Imunisasi Dasar Terhadap Kejadian Stunting Pada Balita Usia 22-36 Bulan Di Wilayah Kerja Puskesmas Kandari Kota Kendari Tahun 2016. Jurnal Ilmiah Mahasiswa Kesehatan Masyarakat, 1(3). Diperoleh dari: http://ojs.uho.ac.id/index.php/JIMKESMAS/article/view/1088.

Thomas, W. S. (2010). Embriologi Kedokteran Langman edisi 10. Jakarta: EGC.

Wiwien, F. W., Martha, I. K., \& Zen, R. (2016). Faktor Risiko Stunting Pada Anak Umur 12-24 Bulan. Jurnal Gizi Indonesia, 5(1), pp. 55-61.

World Health Organization. (2010). Country Profil Indicators: Interpretation Guide, Nutrition Landscape Information System. Geneva, Switzerland. http://doi.org/10.1159/000362780. 